\title{
KONSTITUSIONALITAS MODEL PENGISIAN JABATAN WAKIL KEPALA DAERAH DALAM PENYELENGGARAAN PEMILIHAN KEPALA DAERAH (PILKADA)
}

\author{
Wilda Prihatiningtyas \\ wilda@fh.unair.ac.id \\ Universitas Airlangga
}

\begin{abstract}
The local government is very important in the context of unitary state according to Indonesia Constitution (UUD NRI 1945). There is no constitution in the world that does not regulate important thing regarding to local government or state government explicitly. Therefore formulations charging a place on local government may be related parameter early governance in the region. There are 2 (two) important issues relating to constitutionality of model charging office deputy head of the regions in the regional head election. First, standing of deputy head based on the laws. Second, constitutionality of model charging office deputy head of the regions based on Law No. 1/2015 jo Law No. 8/2015. In this paper, there are 2 (two) models in placing the position of deputy head of region. First, the position is hierarchical under the head of the region with the argument that the deputy head of the region appointed by the head of the region. And second, the position of the deputy head of the region is considered parallel to the regional head because both are directly elected by the people in a package.

Keywords: Local Government; Deputy Head of The Region; Regional Head Election.
\end{abstract}

\begin{abstract}
Abstrak
Kedudukan pemerintahan daerah adalah sangat penting dalam konteks negara kesatuan berdasarkan UUD NRI 1945. Tidak ada konstitusi negara manapun di dunia yang tidak mengatur hal-hal penting berkaitan dengan pemerintahan daerah atau pemerintahan negara-negara bagian secara eksplisit. Oleh karena itu formulasi pengisian jabatan dalam pemerintah daerah dapat menjadi parameter awal terkait penyelenggaraan pemerintahan daerah. Ada 2 (dua) isu penting berkaitan dengan konstitusionalitas model pengisian jabatan wakil kepala daerah dalam penyelenggaraan pilkada. Pertama, kedudukan wakil kepala daerah berdasarkan peraturan perundang-undangan. Kedua, konstitusionalitas model pengisian jabatan wakil kepala daerah berdasarkan UU No. 1/2015 jo UU No. 8/2015. Adapun kesimpulan dalam tulisan ini yakni bahwa terdapat 2 (dua) model dalam menempatkan kedudukan wakil kepala daerah yaitu bersifat hierarkhis di bawah kepala daerah dengan argumentasi bahwa wakil kepala daerah diangkat oleh kepala daerah. Dan kedudukan wakil kepala daerah dianggap sejajar dengan kepala daerah karena keduanya dipilih langsung oleh rakyat dalam satu paket.
\end{abstract}

Kata Kunci: Pemerintahan Daerah; Wakil Kepala Daerah; Pilkada.

\section{Pendahuluan}

Setelah melewati hampir dua dasawarsa pasca reformasi, demokrasi Indonesia telah berkembang sedemikian jauh, menempuh perjalanan panjang dalam rangka mencari format yang paling ideal. Sejarah mencatat bahwa pergerakan reformasi tidak hanya membuka peluang bagi perubahan politik pada tataran nasional, namun juga menjadi momentum penting bagi perubahan politik pada tataran local. Hal ini 
dapat dilihat dari adanya pergeseran sistem pemerintahan nasional yang semula cenderung bercorak otoritarian berubah menjadi demokratis, yang kemudian diikuti pula dengan pergeseran pola hubungan pusat dan daerah dari sentralisasi menjadi desentralisasi, yang pada gilirannya telah melahirkan era otonomi daerah berdasarkan Pasal 18 Ayat 1 Undang-Undang Undang Dasar Negara Republik Indonesia Tahun 1945 (UUD NRI 1945).

Dalam sudut pandang empiris, adanya desentralisasi menjadi jawaban bagi model negara kesatuan seperti Indonesia yang mempunyai latar belakang geografis serta struktur entitas dan kultur politik yang kompleks dan heterogen. Lahirnya daerah-daerah otonom yang ditandai dengan adanya pemerintahan daerah, menurut Larry Diamond, memiliki peran yang cukup penting untuk mempercepat vitalitas demokrasi. ${ }^{1}$ Pandangan tersebut berpijak pada alasan-alasan sebagai berikut. Pertama, pemerintah daerah dapat membantu mengembangkan nilai-nilai dan keterampilan demokrasi terhadap warganya. Kedua, pemerintah daerah dapat meningkatkan akuntabilitas dan pertanggungjawaban kepada berbagai kepentingan di daerahnya. Ketiga, pemerintah daerah dapat menyediakan saluran dan akses tambahan terhadap kelompok-kelompok yang secara historis termarjinalisasi. Dan keempat, pemerintah daerah dapat mendorong terwujudnya check and balances di dalam kekuasaan.

Pemilihan Kepala Daerah (Pilkada) merupakan terminologi paling umum dalam mengidentifikasi penerapan desentralisasi politik yakni dalam praktek penyelenggaraan pemerintahan daerah. Pilkada merupakan instrument penting terhadap upaya demokratisasi di daerah, karena secara instrumental diarahkan untuk membuka kesempatan pada public di daerah untuk terlibat dalam keputusan menyangkut pembangunan di daerahnya, termasuk partisipasi dalam mekanisme pengisian jabatan kepala daerah. Perubahan fundamental seperti ini tentunya berbanding terbalik dengan kondisi selama lebih dari 32 tahun sebelum reformasi, dimana praktik politik yang terjadi cenderung menafikkan peran publik dan justru menjadikan publik tidak lebih sebagai komoditas dan obyek politik daripada sebagai subyek politik.

${ }^{1}$ Larry Diammond, Democracy in Developing Countries - Latin Amerika (1999). 
Sejalan dengan hal tersebut, konstitusi mengamanatkan dalam Pasal 18 Ayat 4 UUD NRI 1945 bahwa "Gubernur, Bupati, dan Walikota masing-masing sebagai kepala pemerintah daerah provinsi, kabupaten, dan kota dipilih secara demokratis." Isu penting yang muncul adalah terkait eksistensi adanya jabatan Wakil Gubernur, Wakil Bupati, ataupun Wakil Walikota. Secara eksplisit, konstitusi hanya mengakui adanya jabatan Gubernur, Bupati, dan Walikota. Berbeda dengan jabatan wakil kepala daerah, UUD NRI 1945 menentukan secara eksplisit adanya jabatan Wakil Presiden sebagaimana ditegaskan dalam Pasal 4Ayat2 UUD NRI 1945, yaitu "Dalam melakukan kewajibannya, Presiden dibantu oleh satu orang Wakil Presiden". Lebih lanjut, dalam Pasal 1 Angka 1 Undang-Undang Republik Indonesia Nomor 1 Tahun 2015 Tentang Penetapan Peraturan Pemerintah Pengganti Undang-Undang Nomor 1 Tahun 2014 Tentang Pemilihan Gubernur, Bupati, Dan Walikota Menjadi Undang-Undang (UU No. 1/2015) disebutkan bahwa "Pemilihan Gubernur, Bupati, dan Walikota yang selanjutnya disebut Pemilihan adalah pelaksanaan kedaulatan rakyat di Provinsi dan Kabupaten/Kota untuk memilih Gubernur, Bupati, dan Walikota secara langsung dan demokratis." Sedangkan dalam Pasal 1 Angka 1 Undang-Undang Republik Indonesia Nomor 8 Tahun 2015 Tentang Perubahan Atas Undang-Undang Nomor 1 Tahun 2015 Tentang Penetapan Peraturan Pemerintah Pengganti Undang-Undang Nomor 1 Tahun 2014 Tentang Pemilihan Gubernur, Bupati, Dan Walikota Menjadi Undang-Undang (UU No. 8/2015), disebutkan bahwa "Pemilihan Gubernur dan Wakil Gubernur, Bupati dan Wakil Bupati, serta Walikota dan Wakil Walikota yang selanjutnya disebut Pemilihan adalah pelaksanaan kedaulatan rakyat di wilayah provinsi dan kabupaten/ kota untuk memilih Gubernur dan Wakil Gubernur, Bupati dan Wakil Bupati, serta Walikota dan Wakil Walikota secara langsung dan demokratis.” Dengan adanya ketentuan tersebut menunjukkan bahwa ada pergeseran pemaknaan terhadap yang dimaksud dengan pemilihan, yaitu pemilihan kepala daerah hanya dimaknai terhadap pemilihan Gubernur, Bupati, dan Walikota saja atau pemilihan kepala daerah adalah satu paket dengan wakil kepala daerahnya.

Kedudukan pemerintahan daerah adalah sangat penting dalam konteks negara kesatuan berdasarkan UUD NRI 1945. Tidak ada konstitusi negara manapun di 
dunia yang tidak mengatur hal-hal penting berkenaan dengan pemerintahan daerah atau pemerintahan negara-negara bagian secara eksplisit. Oleh karenanya formulasi pengisian jabatan dalam pemerintah daerah dapat menjadi parameter awal terkait penyelenggaraan pemerintahan di daerah. Dalam kaitannya dengan hal tersebut, seandainya jabatan wakil kepala daerah memang dinilai pentingnya bagi penyelenggaraan pemerintahan daerah, semestinya pengaturannya dimuat dengan jelas dalam Pasal 18 UUD NRI 1945.

Berdasarkan uraian tersebut di atas, setidaknya muncul 2 (dua) isu penting berkaitan dengan konstitusionalitas model pengisian jabatan wakil kepala daerah dalam penyelenggaraan pilkada. Pertama, kedudukan wakil kepala daerah berdasarkan peraturan perundang-undangan. Kedua, konstitusionalitas model pengisian jabatan wakil kepala daerah berdasarkan UU No. 1/2015 jo UU No. 8/2015.

\section{Kedudukan Wakil Kepala Daerah Berdasarkan Peraturan Perundang-Undangan.}

Berdasarkan Pasal 1 UUD NRI 1945, Negara indonesia adalah negara kesatuan, bukan negara serikat atau federal. Negara kesatuan adalah negara yang bersusun tunggal. Suatu bentuk negara yang didalamnya tidak terdapat suatu daerah yang bersifat negara. ${ }^{2}$ Konsekuensi logis bentuk negara kesatuan adalah adanya pelimpahan kewenangan dari pemerintah pusat kepada daerah dengan berprinsip bahwa tidak ada negara dalam negara. ${ }^{3}$

Desentralisasi merupakan penyerahan wewenang pemerintahan oleh pemerintah pusat kepada pemerintah daerah untuk mengatur dan mengurus urusan pemerintahan dalam sistem Negara Kesatuan Republik Indonesia. ${ }^{4}$ Dalam konteks desentralisasi dinegara kesatuan, pada prinsipnya seluruh kewenangan pemerintahan adalah milik pemerintah pusat, namun pemerintah pusat dapat melimpahkan sebagian kewenangan atau urusannya kepada pemerintah daerah berdasarkan

\footnotetext{
${ }^{2}$ Winarno, Paradigma Baru Pendidikan Kewarganegaraan (Bumi Aksara 2008).[82].

${ }^{3}$ Philipus M. Hadjon, Pengantar Hukum Admistrasi Indonesia (Gadjah Mada University Press 2008).

${ }^{4}$ Pasal 1 ayat 7 Undang-undang Nomor 32 Tahun 2004 Tentang Pemerintahan Daerah.
} 
peraturan perundangan-undangan. Adanya kebutuhan dalam mengelola negara kesatuan tersebut merupakan tujuan dari keberadaan pemerintah daerah. Disisi lain juga merupakan bentuk implementasi dari asas otonomi daerah, dimana daerahdaerah memiliki kewenangan untuk mengurus wilayahnya sendiri, yang bertujuan untuk memberikan kesejahteraan kepada masyarakat daerah.

Pemerintah daerah atau lembaga eksekutif daerah merupakan penyelenggara pemerintahan di daerah bersama DPRD serta yang memegang kewenangan administrasi pemerintahan daerah tertinggi. ${ }^{5}$ Pemerintah daerah menggunakan asas desentralisasi dan tugas pembantuan dalam menyelenggarakan pemerintahan daerah.6 Asas desentralisasi merupakan landasan dalam pelaksanaan penyerahan wewenang pemerintahan oleh pemerintah pusat kepada pemerintah otonom. Berdasarkan Pasal 1 Angka 8 Undang-Undang Nomor 23 Tahun 2014 Tentang Pemerintahan Daerah (UU No. 23/2014), bahwa yang dimaksud dengan desentralisasi adalah penyerahan Urusan Pemerintahan oleh Pemerintah Pusat kepada daerah otonom berdasarkan asas toonomi. Sedangkan tugas pembantuan menurut Pasal 1 Angka 11 UU No. 23/2014 adalah penugasan dari Pemerintah Pusat kepada daerah otonom untuk melaksanakan sebagian Urusan Pemerintahan yang menjadi kewenangan Pemerintah Pusat atau dari Pemerintah Daerah provinsi kepada Daerah kabupaten/kota untuk melaksanakan sebagian Urusan Pemerintahan yang menjadi kewenangan Daerah provinsi.

Berdasarkan Undang-Undang Nomor 5 Tahun 1974 Tentang Pokok-Pokok Pemerintahan Di Daerah (UU No. 5/1974), Undang-Undang Nomor 22 Tahun 1999 Tentang Pemerintahan Daerah (UU No. 22/1999), maupun Undang-Undang Nomor 32 Tahun 2004 Tentang Pemerintahan Daerah (UU No. 32/2004), yang dimaksud Pemerintah Daerah adalah Gubernur, Bupati, atau Walikota, dan perangkat daerah sebagai unsur penyelenggara pemerintahan daerah. Sedangkan dalam UU No. 23/2014 yang saat ini berlaku, yang dimaksud dengan Pemerintah Daerah adalah

\footnotetext{
${ }^{5}$ Jimly Asshiddiqie, Pengantar Ilmu Hukum Tata Negara (Rajawali Pers 2009).[323].

${ }^{6}$ Abdullah Rozali, Pelaksanaan Otonomi Luas Dengan Pemilihan Kepala Daerah Secara Langsung (Raja Grafindo Persada 2007).[27].
} 
kepala daerah sebagai unsur penyelenggara Pemerintahan Daerah yang memimpin pelaksanaan urusan pemerintahan yang menjadi kewenangan daerah otonom. Tidak disebutkan secara eksplisit bahwa wakil kepala daerah adalah bagian dari pemerintah daerah. Dengan kata lain, keberadaan wakil kepala daerah berdasarkan peraturan perundang-undangan tersebut masih dapat dikatakan abstrak, mengingat dalam pasal-pasal lain dalam peraturan perundang-undangan tersebut ada yang memposisikan wakil kepala daerah sebagai bagian yang tidak terpisahkan dengan kepala daerah, namun di sisi lain jika merujuk kembali pada pengertian pemerintah daerah tersebut, seolah-olah keberadaan wakil kepala daerah bukanlah sebagai unsur yang penting dalam penyelenggaraan pemerintahan daerah. Lebih lanjut jika mengacu pada Pasal 18 Ayat 4 UUD NRI 1945 disebutkan bahwa Gubernur, Bupati, dan Walikota masing-masing sebagai kepala pemerintahan daerah provinsi, kabupaten dan kota dipilih secara demokratis. Dalam pasal tersebut tidak disebut Tentang wakil kepala daerah, seperti wakil gubernur, wakil bupati atau wakil walikota. Tidak disebutkanya kedudukan wakil kepala daerah secara eksplisit dalam UUD NRI 1945 menimbulkan pertanyaan yaitu apakah kedudukan wakil kepala daerah adalah konstitusional? Hal ini tentu berbeda dengan adanya pengaturan yang eksplisit dalam UUD NRI 1945 tentang eksistensi jabatan wakil presiden dalam penyelenggaraan pemerintahan NKRI.

Dengan melakukan pendekatan perbandingan (comparative approach), bahwa sebenarnya keberadaan wakil kepala daerah, tidak hanya diakui di Indonesia. Akan tetapi seperti di Spanyol, Amerika Serikat, Australia dan Canada. Wakil kepala daerah disebut dengan lieutenant governor yang kurang lebih artinya sama dengan vice governor. Di Australia lieutenant governor berfungsi sebagai administrator atau acting governor. Di beberapa negara bagian, wakil kepala daerah atau dalam sebutannya pada negara bagian yaitu wakil gubernur atau lieutenant governors berfungsi sebagai calon yang akan dipilih pada putaran pemilu selanjutnya, yang siap untuk menduduki jabatan gubernur (stand ready to take up the governor's 
role). ${ }^{7}$ Pemilihan lieutenant governor berbeda dari satu negara dengan negara lain. Ada di negara bagian itu yang memilih gubenur dan wakilnya ini dalam satu paket pasangan calon ada juga yang memilih secara terpisah atau sendiri-sendiri dan bahkan ada pula yag memilih keduanya dalam waktu yang tidak bersamaan (in different election cycles). ${ }^{8}$

Berlakunya UU No. 5/1974 belum memberikan landasan hukum yang kuat terkait keberadaan wakil kepala daerah dalam pemerintahan daerah. Dalam Pasal 24 Ayat 1 UU No. 5/1974, disebutkan bahwa Wakil Kepala Daerah diangkat oleh pejabat yang berwenang dari PNS yang memenuhi syarat, dan pada ayat 5 nya Pengisian jabatan Wakil Kepala Daerah dilakukan menurut kebutuhan. Dengan melakukan interpretasi sistematis, kedudukan wakil kepala daerah pada masa undang-undang ini, tidak merupakan suatu keharusan. Sifatnya tentative. Apabila dibutuhkan banyak tergantung dari kondisi daerah, wakil kepala daerah bisa lebih dari satu, dan apabila tidak dibutuhkan sama sekali. Suatu daerah yang tidak memiliki wakil kepala daerah tidak menjadi masalah. Lebih lanjut, poin penting mengenai kedudukan wakil kepala daerah dalam UU ini, yaitu :

1. Wakil kepala daerah haruslah pegawai Negeri yang memenuhi persyaratan;

2. Wakil kepala daerah dapat diangkat tanpa melalui pemilihan;

3. Pengisian wakil kepala daerah adalah sesuai dengan kebutuhan;

4. Pelantikan wakil kepala daerah adalah terpisah dengan pelantikan kepala daerah. Namun dalam undang-undang ini juga belum mengatur mengenai tugas atau kewenangan wakil kepala daerah secara rinci, sehingga kedudukan wakil kepala daerah tergantung pada kewenangan yang diberikan oleh kepala daerah.

UU No. 22/1999 untuk pertama kalinya memberikan landasan hukum bagi kekuasaan pemerintah daerah yang memberi ruang bagi kehadiran jabatan wakil kepala daerah. Dalam Pasal 30 UU No. 22/1999 disebutkan bahwa "Setiap daerah dipimpin oleh seorang kepala daerah sebagai kepala eksekutif yang dibantu oleh seorang wakil kepala daerah." dalam UU ini, wakil kepala daerah sudah dibatasi

\footnotetext{
${ }^{7}$ Jimly Asshiddiqie, Perkembangan Dan Konsolidasi Lembaga Negara Pasca Reformasi (Sinar Grafika 2010).[246].

${ }^{8}$ ibid.[247].
} 
menjadi satu wakil dan dipilih dalam satu pasang yang pengisiannya dilakukan oleh DPRD. Ada beberapa poin perubahan dalam UU ini dibandingkan dengan UU No. 5/1974 yaitu:

1. Menghapuskan persyaratan wakil kepala daerah harus dari kalangan pegawai negeri, sehingga membuka kesempatan bagi siapa saja baik yang dari luar pemerintahan ataupun bukan pegawai negeri untuk menduduki posisi wakil kepala daerah.

2. Jika sebelumnya keberadaan wakil kepala daerah disesuaikan dengan kebutuhan daerah, dalam UU ini semua daerah hanya memiliki satu orang wakil kepala daerah.

3. Pelantikan kepala daerah dan wakil kepala daerah dilakukan bersamaan.

4. Lahirnya undang-undang ini menjadi awal dimulainya pemilihan umum dengan sistim paket yang menampilkan satu pasangan calon kepala daerah dan wakil kepala daerah.

5. Wakil kepala daerah bertanggung jawab kepada kepala daerah.

6. Terjadi pergeseran kedudukan wakil kepala daerah, dimana saat mencalonkan diri dalam satu pasangan, kedudukan calon kepala daerah dan wakilnya adalah sama, tetapi setelah menjabat kedudukan kepala daerah lebih tinggi karena wakil kepala daerah harus bertanggung jawab kepada kepala daerah.

Dengan demikian, UU No. 22/1999 telah memberikan kewenangan yang lebih jelas kepada wakil kepala daerah, dibandingkan dengan UU sebelumnya. Walaupun pasal-pasal yang mengatur kedudukan dan tugas wakil kepala daerah didalam UU ini sebetulnya bukanlah kedudukan dan tugas yang khas. Substansi kedudukan dan tugas-tugas ini tidak berbeda jauh dengan kedudukan dan tugas Sekretaris Daerah, yakni "membantu dan bertanggungjawab" kepada Kepala Daerah. ${ }^{9}$

UU No. 32/2004 jo UU No. 12/2008 pun mengisyaratkan hal yang sama, yaitu mengakui keberadaan wakil kepala daerah dalam satu paket dengan kepala daerah. Perbedaannya hanya terletak pada proses pemilihannya, dimana kepala daerah dan wakilnya tidak lagi dipilih oleh DPRD, melainkan dipilih langsung oleh rakyat. Dalam Pasal 26 UU No. 12/2008, terdapat beberapa poin penting, yaitu :

a. Jabatan wakil Kepala Daerah sifatnya membantu dan menyukseskan Kepala Daerah dalam memimpin daerah, melaksanakan tugas tertentu, menggantikan Kepala Daerah bila berhalangan. Namun perlu di ingat bahwa keberadaan

\footnotetext{
9 Agus Sutisna, 'Pemda Tanpa Wakil Kepala Daerah' (Kompasiana, 2012) <https://www. kompasiana.com/www.tisna_1965.com/pemda-tanpa-wakil-kepala-daerah_550d3b7ba333116e1c2 e3a85>.
} 
wakil Kepala Daerah merupakan satu kesatuan yang tidak terpisahkan dan dipilih berpasangan secara langsung oleh rakyat, bersama-sama memimpin dan menyelenggarakan pemerintahan daerah;

b. Tugas dan wewenang wakil bersifat umum, kekuasaan penuh ada di Kepala Daerah dan akhirnya ini memunculkan kegamangan wakil Kepala Daerah dalam bertindak. Ada baiknya Kepala Daerah membina hubungan dengan wakil Kepala Daerah dan memberikan peluang kepada wakil Kepala Daerah sesuai dengan kontrak politik yang dibuat ketika mereka diangkat menjadi satu pasangan calon Kepala Daerah;

c. Tidak terdapat indikator yang mengungkapkan wakil Kepala Daerah dianggap bekerja efektif atau tidak efektif bekerja.

Selanjutnya dalam UU No. 23/2014 diatur dalam Pasal 63 yaitu bahwa Kepala daerah dapat dibantu oleh wakil kepala daerah. Wakil kepala daerah untuk Daerah provinsi disebut wakil gubernur, untuk Daerah kabupaten disebut wakil bupati, dan untuk Daerah kota disebut wakil wali kota. Dalam UU ini semakin menunjukkan bahwa tugas wakil kepala daerah adalah dalam rangka membantu kepala daerah, namun kewenangannya tidak diatur. Hal ini logis mengingat wakil kepala daerah seyogyanya memang dipandang sebagai "bawahan" dari kepala daerah dengan kata lain ada hubungan hierarkhi diantara keduanya. Sehingga kewenangan itu logis jika hanya ada pada kepala daerah, namun kepala daerah dapat melimpahkan kewenangan tersebut secara mandat kepada wakil kepala daerah. Berkenaan dengan mekanisme pemilihan kepala daerah maupun wakilnya, tidak diatur dalam UU ini karena sesuai Pasal 62 disebutkan bahwa "Ketentuan mengenai pemilihan kepala daerah diatur dengan undang-undang", sehingga lahirlah UU No. 1/2015 jo. UU No. 8/2015.

Kemudian berdasarkan UU No. 1/2015, kedudukan wakil kepala daerah adalah berada di bawah kepala daerah. Hal ini logis mengingat wakil kepala daerah senyatanya dipilih oleh kepala daerah dengan mendasarkan pada kriteria sebagaimana diatur dengan UU. Sedangkan dalam UU No. 8/2015, karena mekanisme pemilihan kepala daerah dan wakil kepala daerah dalam satu paket seakan-akan menunjukkan bahwa kedudukan wakil kepala daerah adalah sama kuatnya dengan kepala daerah. 
Proses pemilihan dengan model satu paket antara kepala daerah dan wakil kepala daerah melalui mekanisme pemilihan langsung membawa konsekuensi politik, bahwa posisi politik wakil kepala daerah menjadi sama penting dengan kepala daerah, karena wakil kepala daerah juga mendapat legitimasi langsung dari rakyat. Dan ini terutama diindikasikan oleh rangkaian prosesi pencalonan, pengambilan sumpah dan pemberhentian/pengunduran diri wakil kepala daerah dalam masa jabatanya. ${ }^{10}$ Tetapi dari sisi manajemen kepemerintahan, kedudukan dan tugas wakil kepala daerah tidak mengalami banyak perubahan substantif, kecuali penambahan beberapa tugas operasional. Intinya tetap sama, yakni "membantu tugas-tugas" dan bertanggungjawab kepada Kepala Daerah. Demikian pula halnya dengan kedudukan dan tugas Sekretaris Daerah. ${ }^{11}$

Sebagai contoh, dalam banyak hal substantif, kedudukan dan tugas-tugas kepemerintahan wakil kepala daerah dan Sekretaris Daerah sebetulnya bisa saling dipertukarkan. Yang membedakan keduanya hanya terletak pada konsepsi posisional yang mendikotomikan antara aspek politik dan pemerintah. wakil kepala daerah menduduki jabatan/posisi politik; sedangkan Sekretaris Daerah menduduki jabatan/posisi birokrasi (pemerintah). Hakikat kedudukan dan tugas kepemerintahan keduanya, sekali lagi, tidak berbeda jauh, jika tidak dapat dikatakan sama dan sebangun. ${ }^{12}$

Dengan kondisi seperti ini, banyak yang beranggapan bahwa tanpa wakil kepala daerah pun, penyelenggaraan pemerintahan daerah sebetulnya tetap dapat diselenggarakan dengan baik, sepanjang terdapat masih ada jabatan Sekretaris Daerah, dan banyak juga yang berpendapat bahwa jabatan wakil kepala daerah adalah jabatan yang mubazir13 dikarenakan wakil kepala daerah juga diberi fasilitas seperti rumah dinas, mobil dinas dan fasilitas lain.

\footnotetext{
10 ibid.

11 ibid.

12 ibid.

${ }^{13}$ Rusdianto, 'Eksistensi Wakil Kepala Daerah Dalam Sistem Penyelenggaraan Pemerintahan Daerah' (Blogspot, 2013) <http://wwwpsikologcint.blogspot.com/2013/02/eksistensi-wakil-kepaladaerah-dalam.html>.
} 
Pada dasarnya kedudukan wakil kepala daerah mendapat sorotan karena beberapa hal. Pertama, posisi wakil kepala daerah dinilai tidak efektif dalam menjalankan tugas dan wewenang, sehingga terkesan tumpang tindih dengan tugas dan wewenang kepala daerah. Penilaian ini biasanya didasarkan kepada praktek yang terjadi di mana wakil kepala daerah menjalankan "tugas sisa" yang tidak dilakukan oleh kepala daerah. Hal ini yang kemudian mendasari dilakukannya revisi UU No. 32 Tahun 2004 menjadi UU No. 12 Tahun 2008 terutama berkaitan dengan penegasan tugas dan wewenang wakil kepala daerah. Menurut hemat penulis menanggapi masalah ini, kedudukan wakil kepala daerah senyatanya masih diperlukan. Hal ini mengingat bahwa urusan pemerintah daerah cukup banyak dan cukup berat. Dalam konteks daerah otonom, hampir semua urusan pemerintahan didesentralisasikan ke daerah kecuali urusan-urusan tertentu (pertahanan, keamanan, luar negeri, agama, dan keuangan fiskal dan moneter). Dengan demikian nampaknya masih diperlukan jabatan wakil kepala daerah dalam rangka membantu tugas kepala daerah dalam menjalankan urusan pemerintah daerah. Namun, apabila jabatan wakil kepala daerah masih dipertahankan, maka yang diperlukan adalah penegasan kembali soal pembagian tugas dan wewenang antara kepala dan wakil kepala daerah. Kendatipun wakil kepala daerah hanya "membantu" dan keputusan tetap berada di tangan kepala daerah, namun untuk menghindari tumpang tindih pembagian tugas dan wewenang, tetap diperlukan pengaturan tugas dan wewenang di antara mereka dan pengaturan itu berada di tingkat undang-undang.

Kedua, dalam praktek dipertanyakan soal mekanisme pengisian jabatan wakil kepala daerah, yaitu apakah masih perlu dipertahankan mekanisme pengisian jabatan wakil kepala daerah satu paket pasangan dengan kepala daerah yang kemudian dipilih langsung lewat pemilu, atau wakil kepala daerah cukup diisi dengan cara penunjukkan yang berasal dari PNS senior setelah kepala daerah terpilih lewat pemilu?.

Berdasarkan uraian di atas, merujuk pada peraturan perundang-undangan yang pernah berlaku di Indonesia mengenai kedudukan wakil kepala daerah, maka prinsip yang harus dipahami adalah bahwa sejatinya hubungan antara kepala daerah 
dan wakilnya semestinya dimaknai sebagai hubungan hierarkhis. Dengan kata lain kedudukan wakil kepala daerah disini tidak semestinya dengan mekanisme pengisian jabatan kepala daerah dan wakilnya, apakah dipilih secara bersama-sama melalui pemilihan langsung ataupun ketika wakil kepala daerah dipilih sendiri oleh kepala daerah. Dengan demikian konflik horizontal yang seringkali terjadi antara kepala daerah dan wakilnya dapat diminimalisir.

\section{Konstitusionalitas Model Pengisian Jabatan Wakil Kepala Daerah Berdasarkan UU No. 1/2015 Jo UU No. 8/2015.}

Reformasi yang menghasilkan empat tahap perubahan UUD NRI 1945 telah membawa dampak perubahan besar dalam sistem hukum dan ketatanegaraan Indonesia. Sistem yang diadopsi merupakan sesuatu yang sangat baru bagi Indonesia dalam arti terbentuknya penataan kekuasaan negara secara berbeda dari konsep dalam Undang-Undang Negara Republik Indonesia Tahun 1945 (UUD 1945) sebelum perubahan. Organisasi kekuasaan negara yang bersifat horizontal fungsional telah menggantikan bentuk yang vertikal hirarkis. Dalam konfigurasi kekuasaan yang vertikal hierarkis, Majelis Permusyawaratan Rakyat (MPR) sebagai lembaga negara tertinggi berada di puncak susunan kekuasaan. Kedaulatan adalah di tangan rakyat, namun dilaksanakan sepenuhnya oleh MPR. Majelis ini dianggap sebagai penjelmaan rakyat yang memegang kedaulatan rakyat.

Perubahan Ketiga UUD NRI 1945 menghasilkan pergeseran ke arah susunan kekuasaan yang bersifat horizontal fungsional, dimana kedudukan lembaga-lembaga negara menjadi setara. Masing-masing lembaga negara sebagai penyelenggara kekuasaan negara melakukan pengawasan secara fungsional terhadap lembaga negara lainnya. Perubahan yang dilakukan bertujuan untuk menyempurnakan aturan dasar penyelenggaraan negara secara demokratis dan modern, antara lain melalui pemisahan dan/atau pembagian kekuasaan yang lebih tegas, sistem check and balances yang lebih ketat dan transparan, serta pembentukan lembaga-lembaga negara yang baru untuk mengakomodasi perkembangan kebutuhan bangsa dan tantangan zaman. Kedaulatan rakyat yang sebelumnya dilaksanakan sepenuhnya 
oleh MPR sebagai perwujudan seluruh rakyat maka setelah Perubahan Ketiga UUD NRI 1945, dilaksanakan menurut Undang-Undang Dasar. Hal itu berarti MPR tidak lagi menjadi lembaga negara tertinggi yang dalam kedudukannya sebagai penjelmaan seluruh rakyat, bertugas memberi mandat kepada penyelenggara negara lainnya, yang wajib memberikan pertanggungjawaban pelaksanaan mandat yang diberikan. Dengan demikian, MPR hanya menjadi salah satu lembaga negara di antara lembaga negara lainnya yang memiliki kedudukan setara, namun dengan tugas, kewenangan, dan fungsi yang berbeda. Pernyataan bahwa Indonesia ialah negara yang berdasarkan hukum (rechtsstaat) dan tidak berdasarkan kekuasaan belaka (machtsstaat), sebagaimana termuat dalam Penjelasan UUD 1945 sebelum perubahan, telah dimuat menjadi materi norma dalam batang tubuh Undang-Undang Dasar 1945 hasil perubahan. Dengan demikian terjadi pergeseran dari sistem supremasi parlemen (MPR merupakan lembaga tertinggi negara) menjadi sistem supremasi konstitusi dimana konstitusi ditempatkan sebagai hukum yang tertinggi. Konstitusi menjadi sumber legitimasi dari peraturan perundang-undangan yang dibentuk dan berlaku. Pernyataan bahwa kedaulatan di tangan rakyat yang dilaksanakan berdasarkan Undang-Undang Dasar serta pernyataan bahwa Negara Indonesia adalah negara hukum, dapat dilihat sebagai pendirian yang tegas bahwa prinsip penyelenggaraan negara secara demokratis didasarkan pada konstitusi (constitutional democracy).

Ada tiga ciri utama yang menandai prinsip supremasi konstitusi, ${ }^{14}$ yaitu: (i) pembedaan antara norma hukum konstitusi dan norma hukum lainnya; (ii) keterikatan penguasa terhadap Undang-Undang Dasar; dan (iii) adanya satu lembaga yang memiliki kewenangan untuk menguji konstitusionalitas undang-undang dan tindakan hukum Pemerintah. Meskipun ciri tersebut merupakan ciri yang dikenal dalam sistem negara lain, tetapi hal itu juga merupakan ciri yang diterima dan diakui secara universal. Diadopsinya prinsip supremasi konstitusi dalam perubahan UUD NRI 1945 sudah barang tentu menimbulkan banyak permasalahan yang tidak dapat dilihat secara sederhana. Masalah utama yang dihadapi adalah bagaimana

${ }^{14}$ Jimly Asshiddiqie, Konstitusi \& Konstitusionalisme Indonesia (Revisi, Konstitusi Press 2005). 
menjamin bahwa prinsip tersebut dipatuhi sehingga terdapat konsistensi dan harmonisasi dalam pembuatan peraturan perundang-undangan dan penyusunan kebijakan negara dengan menempatkan UUD NRI 1945 sebagai hukum tertinggi. Hal tersebut meliputi bentuk kelembagaan yang ditugasi untuk menegakkan prinsip supremasi konstitusi tersebut serta bagaimana mekanisme pelaksanaannya.

Sebagai jawaban atas permasalahan tersebut, dalam Perubahan Ketiga UUD NRI 1945 telah diatur keberadaan sebuah Mahkamah Konstitusi (MK) sebagai bagian dari cabang kekuasaan kehakiman yang salah satu kewenangannya adalah melakukan pengujian undang-undang terhadap UUD 1945. Namun berbeda dengan sistem yang dikenal di Amerika Serikat, kewenangan khusus untuk mengawal konstitusi disusun sebagai bagian dari kewenangan Supreme Court (Mahkamah Agung). Sedangkan Indonesia membentuk lembaga yang berdiri sendiri, terpisah dari Mahkamah Agung.

Salah satu kewenangan MK berdasarkan Pasal 24 C Ayat 1 UUD NRI 1945 adalah untuk menguji undang-undang terhadap Undang-Undang Dasar. Pengujian ini baik secara formal (formele toetsing), yaitu menguji keabsahan kelembagaan, bentuk, dan tatacara atau prosedur pembentukan undang-undang maupun secara materil, yaitu menguji konsistensi dan kesesuaian substansi materi undang-undang, baik pasal, ayat atau bagian undang-undang dengan prinsip dan jiwa UUD NRI 1945. Dengan kata lain MK berwenang melakukan pengujian konstitusionalitas suatu UU.

Dalam kaitannya dengan pengaturan mengenai jabatan wakil gubernur, bupati, dan walikota yang dipilih secara langsung dan sepaket dengan pemilihan gubernur, bupati, dan walikota sebagaimana diatur dalam UU No. 8/2015, maka muncul pertanyaan kritis berkaitan dengan konstitusionalitasnya, mengingat dalam Pasal 18 Ayat 4 UUD NRI 1945 disebutkan bahwa "Gubernur, Bupati, dan Walikota masing-masing sebagai kepala pemerintah daerah provinsi, kabupaten, dan kota dipilih secara demokratis." Secara eksplisit, tidak ada pengakuan yang tegas terhadap jabatan wakil gubernur, bupati, dan walikota dalam konstitusi sebagaimana halnya jabatan wakil menteri. Hal ini tentu berbeda dengan adanya pengakuan jabatan wakil presiden. 
Jika dikaitkan dengan uraian sebelumnya, telah dijelaskan mengenai kedudukan wakil kepala daerah dalam penyelenggaraan pemerintahan daerah berdasarkan peraturan perundang-undangan yang berlaku. Secara umum, keberadaan wakil kepala daerah selalu dimungkinkan keberadaannya dalam penyelenggaraan pemerintahan daerah, walaupun tidak ada kewajiban mutlak bahwa setiap daerah harus memiliki wakil kepala daerah sebagaimana pada saat berlakunya UU No. 5/1974. Artinya, keberadaan wakil kepala daerah ini semestinya juga masih perlu dipertanyakan, lebih lanjut mengenai mekanisme pengisian jabatannya juga masih perlu diperdebatkan dengan melihat kondisi ketidakharmonisan kepala daerah dan wakilnya yang selama ini sering terjadi.

Setidaknya ada 3 (tiga) alasan mengapa ada usulan bahwa sebaiknya jabatan wakil kepala daerah dihapuskan saja. Pertama, secara konstitusional UUD NRI 1945 tidak ada menyebutkan posisi wakil kepala daerah. Pasal 18 ayat 4 UUD 1945 hanya menyebutkan kepala daerah saja. Munculnya wakil kepala daerah karena penganalogian para pembuat UU terhadap presiden dan wakil presiden, padahal secara konstitusional wakil kepala daerah tidak masuk dalam pengaturan mengenai pemerintah daerah dalam UUD 1945. Jika keberadaan wakil kepala daerah dihapuskan tidak akan menciderai nilai-nilai konstitusional.

Kedua, jabatan wakil kepala daerah tidak efektif dan memboroskan anggaran. Memang ada yang mengatakan demokrasi itu mahal harganya, tapi penulis menilai pemborosan anggaran untuk demokrasi adalah demokrasi yang kebablasan. Tentunya anggaran yang dialokasikan terbuang percuma jika posisinya hanya sebagai kacung atau pesaingnya kepala daerah. Lemahnya posisi kedudukan, fungsi dan tugas Wakil kepala daerah merupakan ketidak efektifan dalam penyelenggaraan pemerintah daerah. Jika jabatan ini dihapuskan tentunya dapat mengemat triliunan rupiah dan dana dapat dialokasikan untuk pembangunan daerah.

Ketiga, alasan historis-yuridis bahwa sejarah peraturan perundang-undangan tentang pemerintah daerah selalu memposisikan wakil kepala daerah sebagai pelengkap. Wakil kepala daerah diposisikan dibawah kepala daerah. Kewenangan dan tugasnya hanya melaksanakan hal yang bersifat koordinasi, fasilitasi, 
pembinaan, dan pengawasan, monitoring serta tugas-tugas lain yang sebenarnya bisa dilaksanakan dan masuk tupoksi SKPD atau lembaga teknis daerah lainya. Posisi yang tidak setara ini memantikan persaingan yang tidak sehat antara wakil dan kepala daerah. Sebenarnya pelaksanaan roda dan birokrasi pemerintah daerah sudah dilaksanakan oleh Sekretaris Daerah bukan wakil kepala daerah..

Keempat, menghindari konflik penyelenggaraan pemerintah daerah. Pengalaman Pemilukada dalam lima tahun belakangan hanya 5,16\% pasangan calon kepala daerah dan wakilnya yang tetap dalam satu paket maju kembali mencalonkan diri sedangkan 94,84\% kepala daerah membentuk tim baru lagi dan saling berhadapan. Hubungan antara kepala daerah dan wakilnya menjadi runyam dikarenakan masing-masing ingin menyosialisasikan diri kepada calon pemilih sedini mungkin dengan berbagai cara.

Dengan adanya fakta demikian, dalam sub-bab ini penulis akan berusaha mengkritisi setidaknya 2 (dua) hal, yaitu berkaitan dengan konstitusionalitas jabatan wakil kepala daerah dan yang kedua berkaitan dengan konstitusionalitas mekanisme pengisian jabatan kepala daerah beserta wakilnya melalui metode pilkada langsung dalam satu paket berdasarkan UU No. 8/2015. Hal ini penting mengingat tidak menutup kemungkinan di masa yang akan datang, terdapat gugatan judicial review ke MK karena adanya kerugian konstitusionalitas yang ditimbulkan dengan adanya pengaturan dalam UU No. 8/2015.

Pertama, yaitu berkaitan dengan konstitusionalitas jabatan wakil kepala daerah. Secara eksplisit, memang benar bahwa tidak ada satu pasal-pun dalam konstitusi yang menyebut nomenklatur Wakil Gubernur, Wakil Bupati, ataupun Wakil Walikota. Hal ini sama halnya dengan penyebutan wakil menteri yang juga tidak dikenal dalam konstitusi, namun muncul dalam peraturan perundangundangan di bawahnya. Untuk menganalisa hal ini, kiranya dapat dirujuk Putusan MK No. Nomor 79/PUU-IX/2011 Tentang Pengujian Undang-Undang Nomor 39 Tahun 2008 Tentang Kementerian Negara terhadap Undang-Undang Dasar Negara Republik Indonesia Tahun 1945. Dalam salah satu poin pokok permohonannya disebutkan bahwa jabatan wakil menteri sebagaimana diatur dalam Pasal 10 Undang- 
Undang Nomor 39 Tahun 2008 Tentang Kementerian Negara, adalah tidak diatur dalam Pasal 17 UUD NRI 1945 sehingga bertentangan dengan ketentuan Pasal 17 UUD NRI 1945. Bahwa dalam Pasal 17 UUD NRI 1945 tidak mengenai istilah atau jabatan Wakil Menteri, sehingga pengangkatan wakil menteri yang dilakukan oleh Presiden pada Kabinet Indonesia Bersatu Jilid II yang bersandarkan pada Pasal 10 Undang-Undang Nomor 39 Tahun 2008 Tentang Kementerian Negara adalah bertentangan dengan Konstitusi, apalagi sudah sangat jelas jabatan wakil menteri tidak ada dalam susunan organisasi kementerian sebagai mana diatur dalam Pasal 51 Peraturan Presiden Nomor 47 Tahun 2009 Tentang Pembentukan dan Organisasi Kementerian Negara, untuk jelasnya Pemohon kutip bunyi selengkapnya Pasal 51 Peraturan Presiden Nomor 47 Tahun 2009 Tentang Pembentukan dan Organisasi Kementerian Negara, yaitu sebagai berikut:

Pasal 51

"Susunan organisasi Kementerian yang menyelenggarakan fungsi sebagaimana dimaksud dalam Pasal 50 terdiri atas unsur:

a. pemimpin, yaitu Menteri;

b. pembantu pemimpin, yaitu sekretariat kementerian;

c. pelaksana, yaitu deputi kementerian; dan

d. pengawas, yaitu inspektorat kementerian.»

Menurut saksi Pemohon, yaitu Yusril Ihza Mahendra, menyebutkan bahwa:

- Pasal 17 ayat 1 UUD 1945 menyatakan, Presiden dibantu oleh menteri-menteri negara, tidak ada norma yang menyebutkan keberadaan wakil menteri bahkan pada saat rancangan Undang-Undang yang diserahkan kepada Presiden pada tahun 2007 keberadaan jabatan wakil menteri tidak ada dalam draf;

- Keberadaan wakil menteri baru muncul pada Pasal 10 Undang-Undang Nomor 39 Tahun 2008 Tentang Kementerian Negara. Hal ini sama keadaannya dengan Pasal 18 ayat 4 UUD 1945 yang normanya menyebutkan, "Gubernur, bupati, dan walikota masing-masing sebagai kepala pemerintahan daerah, kabupaten, dan kota dipilih secara demokratis". Norma ini tidak menyebutkan adanya jabatan wakil gubernur, wakil bupati, dan wakil walikota, namun pada Undang-Undang Nomor 32 Tahun 2004 Tentang Pemerintah Daerah menyebutkan keberadaan para wakil kepala daerah tersebut;

- Pertanyaannya kemudian apakah hal ini dibenarkan jika norma dalam UUD 1945 tidak menyebutkan adanya wakil kepala daerah sementara dalam UndangUndang kemudian menambahkannya dengan keberadaan wakil menteri, wakil gubernur, wakil bupati, dan wakil walikota;

- Pasal 10 Undang-Undang Nomor 39 Tahun 2008 Tentang Kementerian Negara, tidak memenuhi pula syarat formil. Karena menambahkan sebuah norma baru 
yang sama sekali tidak diperintahkan oleh norma Undang-Undang Dasar. Hal yang sama juga berlaku pada Undang-Undang Nomor 32 Tahun 2004 Tentang Pemerintahan Daerah yang menambahkan norma yang tidak diperintahkan oleh Undang-Undang Dasar yakni munculnya keberadaan para wakil kepala daerah;

- Bahwa norma Pasal 10 Undang-Undang Nomor 39 Tahun 2008 Tentang Kementerian Negara secara materiil dan formil tidak sejalan dengan Pasal 17 ayat 1 , ayat 2, dan ayat 3 UUD 1945 yang hanya menyebutkan adanya menterimenteri negara dan bukan wakil menteri.

Selanjutnya saksi Pemohon yang kedua, yaitu Margarito Kamis menyatakan sebagai berikut :

- Bahwa secara substansial, jabatan-jabatan yang diciptakan oleh Bung Karno dengan jawaban wakil menteri pada saat ini memiliki kemiripan dalam substansial yang dipersoalkan kontitusionalitasnya tidak diatur dalam UUD 1945;

- Bahwa Prof. Dr. Jimly Asshiddiqie anggota tim ahli bidang hukum, orang yang pertama kali mengusulkan ayat ini dengan dasar dan harapan yang jelas yaitu mencegah siapapun yang menjadi Presiden nantinya tidak akan membentuk, menggabungkan, dan membubarkan kementerian seenaknya;

- Untuk menghindari kesan setiap kali membentuk kementerian, setiap kali pula itu diperlukan undang-undang, maka Affandi dari TNI Polri secara tegas menyarankan perubahan frasa ditetapkan dengan undang-undang, diganti dengan frasa diatur dalam Undang-Undang. Nalarnya, nilai instriksinya dan makna normatif Pasal 17 ayat 4 UUD 1945 adalah perintah kepada DPR dan Presiden membentuk undangundang yang mengatur syarat-syarat pembentukan, pengubahan, dan pembubaran kementerian. Bukan mengatur organisasi kementerian, apalagi menciptakan jabatan menteri bahkan wakil menteri.

Dengan merujuk pada argumentasi kedua ahli di atas, maka dapat dikatakan bahwa jabatan wakil gubernur, wakil bupati maupun wakil walikota adalah inkonstitusional sebagaimana halnya jabatan wakil menteri.

Namun, setelah mendengarkan keterangan ahli dari Pemerintah maupun keterangan DPR, berikut poin-poin pertimbangan Mahkamah :

Menimbang, bahwa karena ketentuan Pasal 17 UUD 1945 hanya menyebutkan menteri-menteri negara, tanpa menyebutkan wakil menteri, maka menurut Mahkamah kalau menteri dapat diangkat oleh Presiden, logikanya bahwa Presiden pun tentu dapat mengangkat wakil menteri;

Menimbang, bahwa menurut Mahkamah, UUD 1945 hanya mengatur halhal yang pokok sehingga untuk pelaksanaan lebih lanjut diatur dengan Undang-Undang. Berdasarkan ketentuan konstitusi pengangkatan wakil menteri itu adalah bagian dari kewenangan Presiden untuk melaksanakan tugas-tugasnya. Tidak adanya perintah maupun larangan di dalam UUD 1945 memberi arti berlakunya asas umum di dalam hukum bahwa "sesuatu 
yang tidak diperintahkan dan tidak dilarang itu boleh dilakukan" dan dimasukkan di dalam Undang-Undang sepanjang tidak berpotensi melanggar hak-hak konstitusional atau ketentuan-ketentuan lain di dalam UUD 1945. Menurut Mahkamah, baik diatur maupun tidak diatur di dalam UndangUndang, pengangkatan wakil menteri sebenarnya merupakan bagian dari kewenangan Presiden sehingga, dari sudut substansi, tidak terdapat persoalan konstitusionalitas dalam konteks ini. Hal tersebut berarti bahwa bisa saja sesuatu yang tidak disebut secara tegas di dalam UUD 1945 kemudian diatur dalam Undang-Undang, sepanjang hal yang diatur dalam Undang-Undang tersebut tidak bertentangan dengan UUD 1945;

Menimbang, oleh karena pengangkatan wakil menteri itu boleh dilakukan oleh Presiden, terlepas dari soal diatur atau tidak diatur dalam Undang-Undang, maka mengenai orang yang dapat diangkat sebagai wakil menteri menurut Mahkamah, dapat berasal dari pegawai negeri sipil, anggota Tentara Nasional Indonesia, anggota Kepolisian Republik Indonesia, bahkan warga negara biasa, sebab Presiden yang mengangkat wakil menteri adalah pemegang kekuasaan pemerintahan menurut Undang-Undang Dasar [vide Pasal 4 ayat 1 dan Pasal 17 ayat 2 UUD 1945].

Dengan merujuk pada pendapat Mahkamah berkaitan dengankonstitusionalitas jabatan wakil menteri, maka menurut analisa penulis jabatan wakil kepala daerah yang muncul dalam UU namun tidak diatur dalam UUD NRI 1945 tetaplah konstitusional. Berikut poin-poin yang mendasari argumentasi penulis:

1. Tidak semua jabatan publik/negara disebut atau diatur dalam UUD NRI 1945.

Bahkan, hanya sebagian kecil dari banyak jabatan publik/negara yang diatur dalam UUD NRI 1945. Tidak diatur atau disebutnya suatu jabatan publik dalam UUD NRI 1945 tidak lantas menyebabkan jabatan dimaksud bertentangan dengan UUD NRI 1945 bila diadakan. Terlebih bila dasar hukum untuk mengadakannya kuat. Dalam hal pengadaan jabatan wakil kepala daerah, dasar hukumnya adalah Undang-Undang, suatu produk peraturan yang secara hierakhis berada di bawah Undang-Undang Dasar dan Ketetapan MPR. Bila ditarik ke level konstitusi, adalah bukan suatu hal yang bertentangan dengan UUD NRI 1945 apabila Kepala Daerah mengadakan jabatan Wakil Kepala Daerah. Apalagi, kemudian dasar hukum keberadaan Wakil Kepala Daerah tersebut dikuatkan dengan UU Pemerintahan Daerah maupun UU Pilkada.

2. Dalam sejarah penyelenggaraan pemerintahan daerah, Indonesia selalu mengakui eksistensi wakil kepala daerah. 
Lebih lanjut, selain adanya poin-poin argumentasi sebagaimana disebutkan di atas, sejatinya ada beberapa sisi positif diadakannya jabatan wakil kepala daerah dalam penyelenggaraan pemerintahan daerah, yaitu sebagai berikut:

1. Beban dan Kerumitan Pekerjaan Kepala Daerah

Beratnya beban kepala daerah bukan saja karena harus berhadapan dengan DPRD yang sangat kuat, tetapi juga karena meningkatnya keberanian masyarakat untuk melakukan kritik dan menuntut hak-haknya kepada Pemerintah Daerah dan kondisi ekonomi sosial masyarakat yang masih rendah. Ditengah keterbatasan kemampuan Pemerintahan Daerah, kepala daerah harus bisa meningkatkan pelayanan dan kesejahteraan masyarakat daerahnya, disamping harus tetap menjaga keserasian hubungan dengan pemerintah pusat, dan pemerintah daerah lainnya, sekaligus menumbuh kembangkan kehidupan yang demokratis.

2. Kaderisasi Pejabat Publik

Adanya jabatan Wakil kepala daerah membuka peluang adanya proses kaderisasi bagi calon kepala daerah di masa mendatang. Selama ini kaderisasi pimpinan daerah relatif terbatas, karena kepala daerah dan Wakil kepala daerah terpilih tanpa latar belakang pengalaman di bidang pemerintahan yang relatif memadai, padahal posisi kepala daerah sangat strategis dalam menentukan kemajuan daerah, yang akan memberi kontribusi bagi kemajuan bangsa dan negara.

\section{Jumlah Penduduk}

Persoalan jumlah penduduk tentu berbeda antara satu daerah dan daerah lainya. Agar pelayanan publik tetap maksimal, maka daerah-daerah yang memiliki jumlah penduduk yang banyak perlu untuk meningkatkan pula kinerja pemerintahannya. Problematika yang timbul dari jumlah penduduk tidak dapat di selesaikan oleh seorang kepala daerah saja, melainkan dengan bantuan dari Wakil kepala daerah.

Kedua, berkaitan dengan konstitusionalitas mekanisme pengisian jabatan kepala daerah beserta wakilnya melalui metode pilkada langsung dalam satu paket berdasarkan UU No. 1/2015 jo UU No. 8/2015. Ide dasar tulisan ini bermula dari adanya perubahan yang muncul dalam UU No. 8/2015 Tentang Mekanisme Pengisian Jabatan Wakil Kepala Daerah. Jika dalam UU No. 1/2015, pemilihan 
langsung hanya dilakukan bagi calon gubernur, bupati, dan walikota. Hal itu dapat dilihat dalam Pasal 1 Angka 1 UU No. 1/2015 yang menyebutkan bahwa "Pemilihan Gubernur, Bupati, dan Walikota yang selanjutnya disebut Pemilihan adalah pelaksanaan kedaulatan rakyat di Provinsi dan Kabupaten/Kota untuk memilih Gubernur, Bupati, dan Walikota secara langsung dan demokratis.” Sedangkan untuk pengisian jabatan wakil gubernur, bupati, dan walikota diatur dalam Bab XXIII UU No. 1/2015 sebagai berikut:

Pasal 167

(1) Gubernur, Bupati, dan Walikota dibantu oleh Wakil Gubernur, Wakil Bupati dan Wakil Walikota;

(2) Wakil Gubernur, Wakil Bupati dan Wakil Walikota menjalankan tugas membantu Gubernur, Bupati, dan Walikota sesuai dengan ketentuan peraturan perundang-undangan mengenai pemerintahan daerah.

Pasal 168

(1) Penentuan jumlah Wakil Gubernur berlaku ketentuan sebagai berikut:

a. Provinsi dengan jumlah penduduk sampai dengan 1.000.000 (satu juta) jiwa tidak memiliki Wakil Gubernur;

b. Provinsi dengan jumlah penduduk di atas 1.000.000 (satu juta) jiwa sampai dengan 3.000.000 (tiga juta) jiwa memiliki 1 (satu) Wakil Gubernur;

c. Provinsi dengan jumlah penduduk di atas 3.000 .000 (tiga juta) sampai dengan 10.000.000 (sepuluh juta) jiwa dapat memiliki 2 (dua) Wakil Gubernur;

d. Provinsi dengan jumlah penduduk di atas 10.000.000 (sepuluh juta) dapat memiliki 3 (tiga) Wakil Gubernur.

(2) Penentuan jumlah Wakil Bupati/Wakil Walikota berlaku ketentuan sebagai berikut:

a. Kabupaten/Kota dengan jumlah penduduk sampai dengan 100.000 (seratus ribu) jiwa tidak memiliki Wakil Bupati/Wakil Walikota;

b. Kabupaten/Kota dengan jumlah penduduk di atas 100.000 (seratus ribu) jiwa sampai dengan 250.000 (dua ratus lima puluh ribu) jiwa memiliki 1 (satu) Wakil Bupati/Wakil Walikot.

Pasal 171

(1) Gubernur, Bupati, dan Walikota wajib mengusulkan Calon Wakil Gubernur, Wakil Bupati, dan Wakil Walikota dalam waktu paling lambat 15 (lima belas) hari setelah pelantikan Gubernur, Bupati, dan Walikota;

(2) Wakil Gubernur diangkat oleh Presiden berdasarkan usulan Gubernur melalui Menteri;

(3) Wakil Bupati/Wakil Walikota diangkat oleh Menteri berdasarkan usulan 
Bupati/Walikota melalui Gubernur sebagai wakil Pemerintah;

(4) Gubernur, Bupati, dan Walikota yang tidak mengusulkan Calon Wakil Gubernur, Wakil Bupati, dan Wakil Walikota sebagaimana dimaksud pada ayat 1 dikenai sanksi sesuai dengan ketentuan peraturan perundangundangan;

(5) Ketentuan lebih lanjut mengenai tata cara pengusulan dan pengangkatan Wakil Gubernur, Wakil Bupati, dan Wakil Walikota diatur dengan Peraturan Pemerintah.

Dari ketentuan pasal diatas, dapat disimpulkan bahwa metode pengisian jabatan kepala daerah dan wakilnya seperti mengulang kembali pada saat berlakunya UU No. 5/1974, yang mana pengisian jabatan wakil kepala daerah merupakan prerogatif kepala daerah dengan mendasarkan pada kriteria luas wilayah, jumlah penduduk dan beban pekerjaan kepala daerah. Sehingga jumlah wakil gubernur, bupati, dan walikota di setiap daerah bisa jadi tidak sama di setiap daerah. Jika ditarik ke konstitusi, maka pengaturan seperti ini sudahlah tepat mengingat dalam Pasal 18 Ayat 4 UUD NRI 1945 disebutkan bahwa “Gubernur, Bupati, dan Walikota masing-masing sebagai kepala pemerintah daerah provinsi, kabupaten, dan kota dipilih secara demokratis". Artinya model pengisian jabatan pemerintah daerah yang “terpisah" seperti ini adalah konstitusional. Lebih lanjut, dengan adanya model seperti ini, justru dapat meredam adanya gesekan antara kepala daerah dan wakilnya yang pada akhirnya justru mengganggu stabilitas penyelenggaraan pemerintahan daerah dan penyediaan pelayanan publik yang maksimal bagi masyarakat.

Pertanyaan yang muncul berikutnya adalah mengapa sistem pengangkatan wakil kepala daerah sesuai UU No 1/2015 mesti diubah menjadi sistem pemilihan dalam satu paket? Bukankah pengisian jabatan wakil kepala daerah melalui pengangkatan akan dapat menyelesaikan konflik yang terjadi antara kepala daerah dan wakil selama ini? Bukankah penyelesaian masalah hubungan antara kepala dan wakil kepala daerah tentunya tidak harus dijawab dengan mengubah sistem pengisian jabatan wakil kepala daerah? Sebab, persoalan tersebut muncul bukan karena faktor sistem pengisian jabatan semata, melainkan lebih karena soal komunikasi politik di antara keduanya. Kalaupun sistem pengisian yang hendak dikambinghitamkan, mesti diingat bahwa penentuan sistem pengisian jabatan wakil 
kepala daerah tidak hanya mempertimbangkan masalah ketegangan antara kepala dan wakil kepala daerah yang kelak akan muncul, tetapi terdapat berbagai aspek yang juga harus diperhitungkan.

Kemudian jika kita melihat ketentuan dalam UU No. 8/2015 yang merupakan perubahan dari UU No. 1/2015, salah satu perubahan yang mendasar adalah berkaitan dengan model pengisian jabatan pemerintah daerah. Dalam Pasal 1 Angka 1 UU No. 8/2015 disebutkan bahwa "Pemilihan Gubernur dan Wakil Gubernur, Bupati dan Wakil Bupati, serta Walikota dan Wakil Walikota yang selanjutnya disebut Pemilihan adalah pelaksanaan kedaulatan rakyat di wilayah provinsi dan kabupaten/kota untuk memilih Gubernur dan Wakil Gubernur, Bupati dan Wakil Bupati, serta Walikota dan Wakil Walikota secara langsung dan demokratis." Artinya, pemilihan kepala daerah dilaksanakan dengan model sepaket bersama wakilnya. Ketentuan ini seperti kembali lagi pada saat era berlakunya UU No. 32/2004 dimana pemilihan kepala daerah dan wakilnya adalah melalui model "satu paket" dan dilakukan dengan cara pemilihan langsung.

Terkait perubahan ketentuan ini, setidaknya ada 2 (dua) kubu yang sepakat dengan adanya model satu paket dan golongan yang tidak sepakat dengan model satu paket. Kubu yang ingin konsisten dengan UUD NRI 1945 dan tidak sepakat dengan adanya model satu paket berpandangan bahwa dalam konstitusi, khususnya Pasal 18 ayat 4 diatur bahwa hanya gubernur, bupati, dan walikota sebagai kepala daerah provinsi, kabupaten dan kota saja yang dipilih. Sedangkan jabatan wakil gubernur, wakil bupati, dan wakil walikota tidak termasuk jabatan yang dipilih. Karena tidak disebutkan secara eksplisit dalam UUD 1945, maka UU No. 8/2015 yang memilih kepala daerah dan wakil kepala daerah dalam satu paket pemilihan dianggap tidak sejalan dengan konstitusi. Pengisian jabatan wakil kepala daerah semestinya bersifat tentative, sesuai kebutuhan masing-masing daerah, dan diisi melalui mekanisme pengangkatan dari PNS yang memenuhi syarat. (mengikuti pola UU Nomor 5 Tahun 1974).

Sedangkan kubu yang sepakat dengan model satu paket sebagaimana diatur dalam UU No. 8/2015 menganggap bahwa model seperti ini sebagaimana diatur 
dalam UU No. 32/2004 tidak pernah ada yang melakukan uji materiil ke Mahkamah Konstitusi, sehingga dianggap tidak ada yang secara konstitusional dirugikan. Lebih lanjut, dengan adanya model pencalonan satu paket dapat terbangun koordinasi yang baik antara kepala daerah dan wakil kepala daerah sejak awal, sehingga harapan yang muncul adalah penyelenggaraan pemerintahan daerah dapat berjalan dengan baik. ${ }^{15}$

Menurut analisa penulis, ada beberapa hal yang dapat menjadi poin plus manakala pemilihan kepala daerah dan wakilnya adalah dengan model satu paket. Pertama, sistem pengisian wakil kepala daerah berhubungan dengan agenda mewujudkan integrasi politik di daerah. Apabila kepala daerah dan wakil kepala daerah dipilih dalam satu paket, kesempatan terjadinya penggabungan dua kekuatan politik yang episentrumnya ada pada figur keduanya terbuka lebar. Kedua, pemilihan dengan berpasangan menjadi ruang proses kaderisasi kepemimpinan politik di daerah. Proses pemilihan tidak dapat dipungkiri mampu menjadi salah satu wahana menyiapkan kepala daerah yang lebih kapabel dan memiliki komunikasi politik yang lebih baik. Dalam konteks ini, posisi wakil sesungguhnya dapat dinilai sebagai tempat berlatih diri bagi aktivis partai sebelum menjadi kepala daerah. Ketiga, kepala daerah sebagai pemimpin daerah otonom seyogianya didampingi oleh wakil dengan legitimasi yang sama dengannya. Hal itu diperlukan karena jika kepala daerah berhenti atau diberhentikan, penggantinya adalah orang yang juga dipilih rakyat dalam pilkada. Tiga manfaat dimaksud tentunya sulit, bahkan mustahil, dipenuhi jika jabatan wakil kepala daerah diisi menggunakan sistem pengangkatan sebagaimana diatur dalam UU No. 1/2015. Oleh karena itu, adanya perubahan sistem pengisian jabatan wakil kepala daerah sebagaimana diatur dalam UU No 1/2015 menjadi sistem pemilihan langsung satu paket berdasarkan UU No. 8/2015 dapat dikatakan sebagai langkah maju dalam penyelenggaraan demokratisasi di daerah.

Berdasarkan uraian tersebut di atas, dapat disimpulkan bahwa ketentuan mengenai model pengisian jabatan kepala daerah dan wakil kepala daerah dalam satu paket adalah konstitusional, sepanjang dimaknai bahwa kepala daerah dan wakil

${ }^{15}$ Kuntana Magnar, Negara Hukum Yang Berkeadilan Suatu Kumpulan Pemikiran Dalam Rangka Purnabakti Bagir Manan (PSKN-HTN FH Unpad).[276-280]. 
kepala daerah adalah satu kesatuan penyelenggara pemerintah daerah sebagaimana dimaksud dalam Pasal 1 Angka 3 UU No. 23/2014. Dan pengertian penyelenggara pemerintah daerah jika dikaitkan dengan konstitusi sebenarnya merujuk pada pengertian Gubernur, Bupati, dan Walikota sebagaimana diatur dalam Pasal 18 Ayat 4 UUD NRI 1945. Dengan kata lain, ketika kita membaca "Gubernur, Bupati, dan Walikota" dalam Pasal tersebut, haruslah dimaknai "beserta wakilnya" jika konteksnya adalah model pemilihan satu paket melalui pemilihan langsung. Namun hal tersebut tidak menggugurkan adanya kemungkinan wakil kepala daerah yang dipilih sendiri oleh kepala daerah tanpa melalui mekanisme pemilihan langsung.

\section{Kesimpulan}

1. Konsekuensi logis dari bentuk negara kesatuan sebagaimana disebutkan dalam Pasal 1 Ayat 1 UUD NRI 1945 adalah adanya pelimpahan kewenangan dari pemerintah kepada pemerintah daerah yang melahirkan adanya daerahdaerah otonom. Otonomi daerah mustahil berhasil tanpa didukung semangat penyelenggara pemerintah daerah. Berdasarkan UU No. 23/2014, yang dimaksud pemerintah daerah adalah kepala daerah sebagai unsur penyelenggara Pemerintahan Daerah yang memimpin pelaksanaan urusan pemerintahan yang menjadi kewenangan daerah otonom. Keberadaan kepala daerah (dan wakilnya) memegang peranan penting dalam penyelenggaraan pemerintahan daerah. Dalam konstitusi, secara eksplisit tidak dikenal adanya nomenklatur wakil kepala daerah (baik Wakil Gubernur, Bupati, maupun Walikota). Namun, dalam sejarah penyelenggaraan pemerintahan di Indonesia, sejak lahirnya UU No.5/1974, UU No. 22/1999, UU No. 32/2004 jo UU No. 12/2008, UU No. 23/2014, maupun dalam UU No. $1 / 2015$ jo UU No. 8/2015, kedudukan wakil kepala daerah senyatanya diakui, walaupun dengan formulasi yang berbedabeda. Setidaknya ada 2 (dua) model dalam menempatkan kedudukan wakil kepala daerah. Pertama, bersifat hierarkhis di bawah kepala daerah dengan argumentasi bahwa wakil kepala daerah diangkat oleh kepala daerah. Kedua, kedudukan wakil kepala daerah dianggap sejajar dengan kepala daerah karena 
keduanya dipilih langsung oleh rakyat dalam satu paket.

2. Pembahasan mengenai konstitusionalitas model pengisian jabatan wakil kepala daerah berdasarkan UU No. 1/2015 Jo UU No. 8/2015 dibagi menjadi 2 (dua) sub bagian. Pertama, berkaitan dengan konstitusionalitas jabatan wakil kepala daerah. Walaupun jabatan wakil kepala daerah tidak diatur dalam UUD NRI 1945 tidak serta merta dapat dikatakan inkonstitusional. Alasannya, yaitu bahwa pada dasarnya tidak semua jabatan publik/negara disebut atau diatur dalam UUD NRI 1945, misal wakil menteri. Selain itu, dalam sejarah penyelenggaraan pemerintahan daerah, Indonesia selalu mengakui eksistensi wakil kepala daerah dalam peraturan perundang-undangannya dan senyatanya belum pernah ada yang melakukan uji materiil terkait pengaturan tersebut. Kedua, berkaitan dengan konstitusionalitas mekanisme pengisian jabatan kepala daerah beserta wakilnya melalui metode pilkada langsung dalam satu paket berdasarkan UU No. 8/2015. Menurut analisa penulis, ada beberapa hal yang dapat menjadi poin plus manakala pemilihan kepala daerah dan wakilnya adalah dengan model satu paket. Pertama, sistem pengisian wakil kepala daerah berhubungan dengan agenda mewujudkan integrasi politik di daerah. Kedua, pemilihan dengan berpasangan menjadi ruang proses kaderisasi kepemimpinan politik di daerah. Ketiga, kepala daerah sebagai pemimpin daerah otonom seyogyanya didampingi oleh wakil dengan legitimasi yang sama dengannya. Oleh karena itu, adanya perubahan sistem pengisian jabatan wakil kepala daerah sebagaimana diatur dalam UU No 1/2015 menjadi sistem pemilihan langsung satu paket berdasarkan UU No. 8/2015 dapat dikatakan sebagai langkah maju dalam penyelenggaraan demokratisasi di daerah. Lebih lanjut, ketentuan mengenai model pengisian jabatan kepala daerah dan wakil kepala daerah dalam satu paket adalah konstitusional, sepanjang dimaknai bahwa kepala daerah dan wakil kepala daerah adalah satu kesatuan penyelenggara pemerintah daerah sebagaimana dimaksud dalam Pasal 1 Angka 3 UU No. 23/2014. Dan pengertian penyelenggara pemerintah daerah jika dikaitkan dengan konstitusi sebenarnya merujuk pada pengertian Gubernur, Bupati, dan 
Walikota sebagaimana diatur dalam Pasal 18 Ayat 4 UUD NRI 1945. Dengan kata lain, ketika kita membaca "Gubernur, Bupati, dan Walikota" dalam Pasal tersebut, haruslah dimaknai "beserta wakilnya" jika konteksnya adalah model pemilihan satu paket melalui pemilihan langsung. Namun hal tersebut tidak menggugurkan adanya kemungkinan wakil kepala daerah yang dipilih sendiri oleh kepala daerah tanpa melalui mekanisme pemilihan langsung.

Dengan diaturnya kedudukan dan tugas wakil kepala daerah dalam peraturan perundang-undangan sesungguhnya merupakan langkah yang tepat. Namun permasalahannya adalah bahwa politik perundang-undangan mengenai kedudukan wakil kepala daerah hingga saat ini belumlah jelas, apakah kedudukan antara kepala daerah dan wakil kepala daerah adalah bersifat hierarkhis ataukah koordinatif. Oleh karena itu, model politik hukum berkaitan dengan kedudukan wakil kepala daerah haruslah segera dipikirkan, agar ke depannya dapat dituangkan secara jelas dalam peraturan perundang-undangan, sehingga kerancuan dan konflik horizontal yang terjadi dapat terselesaikan dengan baik.

\section{Daftar Bacaan}

\section{Buku}

Abdullah Rozali, Pelaksanaan Otonomi Luas Dengan Pemilihan Kepala Daerah Secara Langsung (Raja Grafindo Persada 2007).

Jimly Asshiddiqie, Konstitusi \& Konstitusionalisme Indonesia (Revisi, Konstitusi Press 2005).

—_, Pengantar Ilmu Hukum Tata Negara (Rajawali Pers 2009).

—_, Perkembangan Dan Konsolidasi Lembaga Negara Pasca Reformasi (Sinar Grafika 2010).

Kuntana Magnar, Negara Hukum Yang Berkeadilan Suatu Kumpulan Pemikiran Dalam Rangka Purnabakti Bagir Manan (PSKN-HTN FH Unpad).

Larry Diammond, Democracy in Developing Countries - Latin Amerika (1999). Philipus M. Hadjon, Pengantar Hukum Admistrasi Indonesia (Gadjah Mada University Press 2008). 
Winarno, Paradigma Baru Pendidikan Kewarganegaraan (Bumi Aksara 2008).

\section{Website}

Agus Sutisna, 'Pemda Tanpa Wakil Kepala Daerah' (Kompasiana, 2012) $<$ https:// www.kompasiana.com/www.tisna_1965.com/pemda-tanpa-wakil-kepala-da erah_550d3b7ba333116e1c2e3a85>.

Rusdianto, 'Eksistensi Wakil Kepala Daerah Dalam Sistem Penyelenggaraan Pemerintahan Daerah' (Blogspot, 2013) < http://wwwpsikologcint.blogspot. com/2013/02/eksistensi-wakil-kepala-daerah-dalam.html>.

HOW TO CITE: Wilda Prihatiningtyas, 'Konstitusionalitas Model Pengisian Jabatan Wakil Kepala Daerah Dalam Penyelenggaraan Pemilihan Kepala Daerah (Pilkada)' (2018) Vol. 1 No. 2 Media Iuris. 